\title{
PENGARUH FAKTOR EKSTERNAL DAN INTERNAL TERHADAP KINERJA UMKM DI KOTA PASURUAN
}

\author{
Vita Fibriyani \\ Jurusan Manajemen Fakultas Ekonomi Universitas Merdeka Pasuruan \\ Email : vitafibriyani@gmail.com ${ }^{1}$ \\ Eva Mufidah \\ Jurusan Manajemen Fakultas Ekonomi Universitas Merdeka Pasuruan \\ eva.moev@gmail.com ${ }^{2}$
}

\begin{abstract}
ABSTRAK
Peranan sektor swasta di negara berkembang seperti Indonesia mengalami peningkatan di era globalisasi. Hal ini merupakan dampak adanya globalisasi perdagangan. Sektor swasta yang berperan penting dalam pertumbuhan ekonomi di Indonesia adalah usaha kecil dan menengah. Tujuan dari penelitian ini adalah untuk mengetahui pengaruh faktor eksternal (aspek kebijakan pemerintah, sosial ekonomi dan peranan lembaga terkait) dan faktor internal (aspek sumber daya manusia, keuangan, operasional dan pemasaran) terhadap kinerja UMKM Kota Pasuruan. Sampel penelitian ini adalah UMKM makanan dan minuman, industri mebel dan industri logam sejumlah 150 sampel. Teknik analisis data yang digunakan dalam penelitian ini adalah analisis regresi linier berganda dengan metode stepwise. Hasil penelitian menunjukkan bahwa kinerja umkm di Kota Pasuruan dipengaruhi oleh aspek pemasaran dan keuangan dari faktor internal serta kebijakan pemerintah dari faktor eksternal. Kinerja umkm Kota Pasuruan dapat dijelaskan oleh ketiga hal tersebut sebesar $18.1 \%$ sedangkan $81.9 \%$ dijelaskan oleh variabel lain yang tidak dilibatkan dalam model. Aspek keuangan merupakan pengaruh dominan dengan nilai signifikansi sebesar 0.003 dan koefisien regresi sebesar 0.239 sedangkan aspek kebijakan pemerintah mempunyai nilai signifikansi sebesar 0.003 dengan koefisien regresi sebesar 0.232. Untuk aspek pemasaran berpengaruh terhadap kinerja umkm Kota Pasuruan dengan nilai signifikansi sebesar 0.018 dan koefisien regresi sebesar 0.190.
\end{abstract}

Kata Kunci : faktor eksternal, faktor internal, kinerja, umkm, regresi linier berganda

\section{PENDAHULUAN}

Peranan sektor swasta di negara berkembang termasuk Indonesia pada era globalisasi ini mengalami peningkatan sebagai dampak adanya globalisasi perdagangan. Sektor swasta yang berperan penting dalam pertumbuhan ekonomi Indonesia adalah usaha kecil dan menengah. Dalam Rokhayati dan Lestari (2016) dijelaskan bahwa usaha mikro kecil dan menengah (UMKM) menjadi salah satu kegiatan usaha yang mendukung ekonomi pedesaan. Perkembangan UMKM sendiri sangat 
lambat dan kalah dalam persaingan dengan perusahaan besar, utamanya di era globalisasi dan perdagangan bebas. Untuk itu, diperlukan suatu solusi untuk meningkatkan kinerja UMKM.

Perkembangan Usaha Mikro Kecil dan Menengah (UMKM) di Indonesia merupakan salah satu prioritas dalam pembangunan ekonomi. Usaha tersebut merupakan tulang punggung ekonomi kerakyatan yang tidak hanya ditujukan untuk mengurangi masalah kesenjangan antar golongan pendapatan dan antar pelaku usaha, ataupun pengentasan kemiskinan dan penyerapan tenaga kerja. Pengembangan usaha mikro mampu memperluas basis di bidang ekonomi dan dapat memberikan kontribusi yang signifikan dalam mempercepat perubahan struktural yaitu dengan meningkatkan perekonomian daerah dan ketahanan ekonomi nasional.

Daya saing yang rendah dari UMKM menyebabkan kelompok usaha mengalami kesulitan dalam meningkatkan output (Tambunan, 2008). Perkembangan peran UMKM ditunjukkan oleh jumlah unit usaha dan pengusaha, serta kontribusinya terhadap pendapatan nasional, dan penyediaan lapangan kerja. Dengan perkembangan UMKM di Kota Pasuruan yang semakin meningkat, dimungkinkan dapat meningkatkan pendapatan per kapita Kota Pasuruan. Agar kinerja UMKM terus meningkat dibutuhkan peran serta para wirausaha dan kompetensi sumber daya manusia (SDM) yang berkualitas. Peran yang dimainkan oleh sektor ini diharapkan akan tetap berlanjut dengan cara pemerintah dan pihak terkait memiliki acuan yang jelas tentang faktorfaktor yang mempengaruhi peningkatan kinerja usaha.

Krisdanti dan Rodhiyah (2014) menjelaskan bahwa kinerja UKM di Kota Semarang dipengaruhi oleh karakteristik UKM, karakteristik entrepreneur, psikologi entrepreneur, sumber daya manusia serta kreatifitas dan inovasi. Hal ini berarti bahwa semakin baik kinerja UKM industri pengolahan makanan di Kota Semarang maka semakin meningkat pula karakteristik UKM, karakteristik entrepreneur, psikologi entrepreneur, sumber daya manusia serta kreatifitas dan inovasi.

Dalam penelitian Lofian dan Riyoko (2014) dijelaskan bahwa SMEs mebel rotan dipengaruhi oleh faktor eksternal dan faktor internal dengan koefisien regresi sebesar 0.535 dan nilai signifikansi 0.012 untuk faktor eksternal serta koefisien regresi untuk faktor 
internal sebesar 0.314 dan nilai signifikansi sebesar 0.003. Kinerja UKM mebel rotan di Jepara dijelaskan oleh faktor eksternal dan internal hanya sebesar $24.2 \%$ sedangkan sisanya dijelaskan oleh variabel lain yang tidak dilibatkan dalam penelitian ini. Teknik analisis data yang digunakan dalam penelitian adalah analisis regresi linier berganda dengan sampel penelitian adalah UKM mebel rotan yang berada di Jepara dengan karakteristik wanita dan pria. Jumlah sampel yang diambil adalah 143 dengan teknik sampling purposive sampling.

Dalam penelitian Rokhayati dan Lestari (2016) menyatakan bahwa kinerja UMKM diukur dengan berbagai aspek lingkungan, faktor internal dan faktor eksternal, dimana faktor internal meliputi aspek sumber daya manusia, keuangan, produksi dan pemasaran sedangkan faktor eksternal meliputi aspek teknologi, kebijakan pemerintah, sosial ekonomi dan peran lembaga terkait. Untuk kinerja dilihat berdasarkan adanya keberhasilan usaha misalnya pertumbuhan penjualan, pertumbuhan tenaga kerja, pertumbuhan laba dan pertumbuhan pasar.

\subsection{Usaha Kecil dan Menengah}

Berdasarkan Undang - Undang Republik Indonesia Nomor 9 tahun 1999 tentang usaha kecil dan koperasi, usaha kecil merupakan suatu kegiatan ekonomi rakyat yang berskala kecil serta memenuhi kriteria kekayaan bersih, hasil penjualan tahunan serta kepemilikan sebagaimana diatur dalam Undang Undang. Dalam Undang - Undang Nomor 20 tahun 2008 dijelaskan bahwa usaha kecil adalah usahha ekonomi produktif yang berdiri sendiri, baik oleh orang perorangan maupun badan usaha yang bukan merupakan anak perusahaan atau bukan cabang perusahaan yang dimiliki. Menurut Badan Pusat Statistik menjelaskan bahwa usaha menenggah merupakan usaha yang memiliki tenaga kerja antara 20 orang sampai 99 orang.

\subsection{Faktor Internal}

Faktor internal merepresentasikan bidang sumber daya manusia, produksi, pemasaran dan pengembangan produk yang memberikan gambaran terhadap keadaan perusahaan. Faktor-faktor internal yang positif dapat digunakan perusahaan untuk mencapai misi, sasaran, dan tujuan. Faktor ini mencakup keterampilan atau pengetahuan, citra publik yang positif, tenaga penjualan yang berpengalaman, pelanggan yang loyal, dan faktor-faktor lainnya. Sebaliknya faktor internal yang negatif 
harus dihindari oleh perusahaan karena akan menghambat perusahaan dalam mencapai tujuan, misalnya kekurangan modal, kekurangan pekerja terampil, tidak mampu menguasai teknologi, dan lokasi yang tidak strategis (Zimmerer et. al.,2008). Faktor internal meliputi area fungsional bisnis, termasuk manajemen, pemasaran, keuangan/akuntansi, produksi, operasi, dan sistem informasi manajemen. Faktor internal menjadi dasar guna membangun tujuan dan strategi dalam menciptakan kekuatan dan mengatasi kelemahan organisasi (David, 2009). Dimensi faktor internal meliputi: (1) aspek sumber daya manusia; (2) aspek keuangan; (3) aspek teknis dan operasional; dan (4) aspek pasar dan pemasaran (Sandra dan Purwanto, 2015).

\subsection{Faktor Eksternal}

Pearce dan Robinson (2011) menjelaskan bahwa faktor eksternal mempengaruhi sebuah perusahaan dalam menentukan arah dan tindakan yang akan dilakukan perusahaan. Faktor eksternal akan mempengaruhi struktur organisasi dan proses internal perusahaan. Faktor eksternal dibagi menjadi 3 sub kategori yang saling berkaitan yaitu: (1) Lingkungan jauh atau remote environment (ekonomi, sosial, politik, teknologi, ekologi); (2) Lingkungan industri atau industry environment (hambatan masuk, kekuatan pemasok, kekuatan pembeli, ketersediaan produk pengganti, persaingan kompetitif; dan (3) Lingkungan operasional atau operating environment (pesaing, pemberi kredit, pelanggan, pasar tenaga kerja, pemasok). Faktor eksternal yang positif akan membantu perusahaan mencapai tujuan. Perusahaan menganalisis faktor-faktor yang paling berpengaruh terhadap perusahaan dengan melihat peluang yang berada di lingkungan eksternal, dan melakukan penyesuaian dengan mempertimbangkan keadaan dan kompetensi inti perusahaan untuk mencapai tujuan (Zimmerer et. al., 2008).

\subsection{Kinerja}

Dalam Rangkuti (2013) dijelaskan bahwa kinerja usaha dapat diukur oleh gabungan dari faktor - faktor eksternal dan internal dalam sebuah organisasi. Kedua faktor digabungkan dalam sebuah analisis SWOT dimana faktor eksternal sebagai Opportunities dan Threats sedangkan faktor internal mewakili Strengths dan Weaknesses. Indikator kinerja menurut Sandra dan Purwanto (2015) meliputi pertumbuhan penjualan, modal tenaga kerja, pemasaran dan laba. 
Berdasarkan kajian teori yang telah dilakukan, adapun model structural yang dibentuk sebagai kerangka berpikir dalam penelitian ini disajikan dalam Gambar 1.

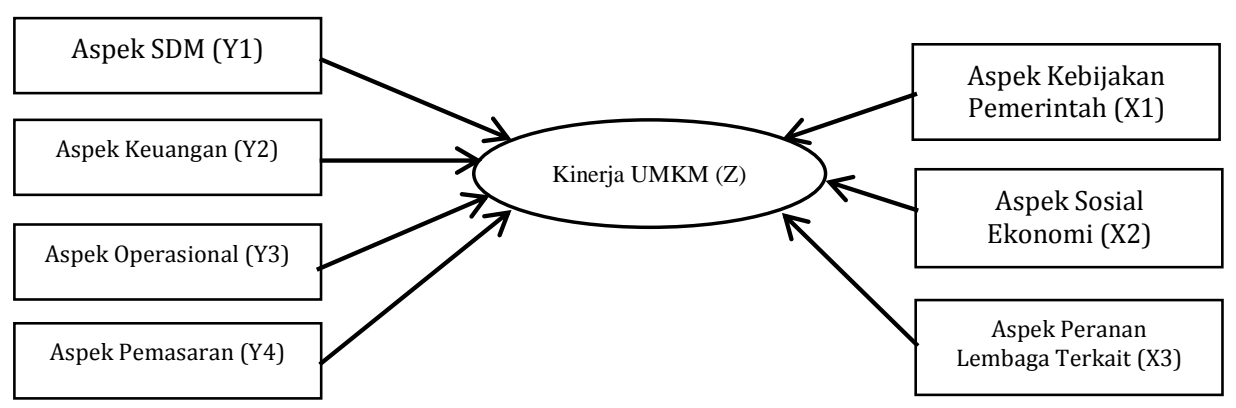

Gambar 1. Kerangka Pikir

Berdasarkan kerangka pikir pada Gambar 1 dan studi pustaka yang telah dilakukan bahwa kinerja umkm dipengaruhi oleh sumber daya manusia, keuangan, operasional, pemasaran, kebijakan pemerintah, sosial ekonomi dan peranan lembaga terkait. Untuk itu peneliti menduga tidak semua variabel independen yang dilibatkan dalam penelitian berpengaruh terhadap kinerja umkm.

\section{METODE PENELITIAN}

Penelitian ini melibatkan 7 variabel independen meliputi aspek kebijakan pemerintah, aspek sosial ekonomi dan aspek peranan lembaga terkait yang termasuk pada faktor eksternal serta aspek sumber daya manusia, aspek keuangan, aspek produksi operasional dan aspek pemasaran yang termasuk pada faktor internal serta 1 variabel dependen yaitu kinerja UMKM. Populasi dalam penelitian ini meliputi semua pelaku atau SDM umkm di Kota Pasuruan yang masih aktif usahanya. Menurut data dari Dinas Koperasi, Perindustrian dan Perdagangan di Kota Pasuruan, jumlah UMKM sebanyak 750 unit. Teknik pengambilan sampel yang digunakan adalah metode purposive sampling. Dari 750 unit UKM akan diambil 150 unit sebagai sampel. Banyaknya sampel yang digunakan adalah $20 \%$ dari jumlah populasi. Data yang digunakan dalam penelitian ini adalah data sekunder dan data primer. Data sekunder meliputi data jumlah UMKM di Kota Pasuruan, sedangkan data primer meliputi data hasil wawancara dari responden yang berkaitan dengan faktor ekternal dan internal yang berpengaruh terhadap kinerja UMKM di Kota Pasuruan. Wawancara dilakukan dengan 
menggunakan alat bantu kuesioner. Teknik analisis data yang digunakan dalam penelitian ini adalah analisis regresi berganda dengan pemilihan model terbaik melalui metode stepwise. Regresi dengan metode stepwise merupakan salah satu teknik analisis regresi untuk memilih himpunan variabel independen terbaik (Fahrmeir et al, 2013; Keith, 2015). Langkah - langkah regresi stepwise adalah sebagai berikut (Hanke dan Wiehern, 2005) :

1. Membuat matriks korelasi antara variabel dependen $(Z)$ dengan variabel independen (X1 - X3 dan Y1 - Y4).

2. Variabel independen yang memiliki koefisien korelasi paling besar dengan variabel dependen adalah variabel pertama yang masuk dalam persamaan regresi.

3. Variabel selanjutnya yang masuk ke persamaan regresi adalah salah satu variabel (selain yang sudah masuk sebelumnya) dengan kontribusi signifikan pada jumlah kuadrat signifikan dari variabel yang masuk pada persamaan regresi yang ditentukan oleh $F$ test. Nilai dari statistik uji $\mathrm{F}$ yang harus dilampaui oleh variabel bebas disebut $F$ to enter.

4. Saat variabel tambahan masuk ke dalam persamaan regresi, kontribusi individu untuk jumlah kuadrat regresi dari variabel lainnya yang sudah masuk dalam persamaan dihitung signifikansinya menggunakan $F$ test. Jika statistik F kurang dari nilai yang disebut $F$ to remove, maka variabel tersebut dihilangkan dari persamaan regresi.

5. Interpretasi mdel yang diperoleh.

\section{HASIL DAN PEMBAHASAN}

\subsection{Hasil Penelitian}

Sebelum dilakukan pengambilan data dengan menggunakan kuesioner, dilakukan pengujian kuesioner meliputi uji validitas dan uji reliabilitas. Pengujian instrumen dilakukan pada 48 responden. Pengujian validitas dilakukan dengan menggunakan koefisien korelasi Pearson, dimana setiap indikator/item pernyataan dinyatakan valid jika mempunyai nilai signifikansi lebih kecil dari taraf nyata $5 \%$. Untuk pengujian reliabilitas dengan menggunakan nilai Alpha Cronbach, dimana suatu konstruk atau variabel dinyatakan reliabel jika memiliki nilai Alpha Cronbach lebih besar dari 0.6 (Arikunto, 2010). Berikut hasil pengujian validitas disajikan dalam Tabel 1, 2 dan 3. 
Tabel 1. Hasil Pengujian Validitas Faktor Eksternal

\begin{tabular}{lccc}
\hline \multicolumn{1}{c}{ Variabel / Indikator } & $\begin{array}{c}\text { Koefisien } \\
\text { Korelasi (r) }\end{array}$ & $\begin{array}{c}\text { Nilai } \\
\text { Signifikansi }\end{array}$ & Keterangan \\
\hline $\begin{array}{l}\text { 1. Aspek Kebijakan Pemerintah } \\
\text { a. Kemudahan perijinan usaha }\end{array}$ & 0.777 & 0.000 & Valid \\
$\begin{array}{l}\text { b. Penyediaan informasi } \\
\text { c. Kegiatan pembinaan melalui dinas terkait }\end{array}$ & 0.873 & 0.000 & Valid \\
2. Aspek Sosial Ekonomi & 0.874 & 0.000 & Valid \\
$\begin{array}{l}\text { a. Keselarasan jalan usaha dan karakteristik } \\
\text { masyarakat }\end{array}$ & 0.747 & 0.000 & Valid \\
$\begin{array}{l}\text { b. Tingkat pendapatan masyarakat } \\
\text { c. Hubungan inovasi produk dengan budaya }\end{array}$ & 0.822 & 0.000 & Valid \\
3. Aspek Peranan Lembaga Terkait & 0.791 & 0.000 & Valid \\
$\begin{array}{l}\text { a. Bantuan pemodalan dari lembaga terkait } \\
\text { b. Bimbingan teknis/pelatihan }\end{array}$ & 0.787 & 0.000 & Valid \\
$\begin{array}{l}\text { c. Pendampingan, monitoring dan evaluasi } \\
\text { d. Pemodalan pengajuan kredit bank }\end{array}$ & 0.823 & 0.000 & Valid \\
\hline
\end{tabular}

Tabel 2. Hasil Pengujian Validitas Faktor Internal

\begin{tabular}{|c|c|c|c|}
\hline Variabel / Indikator & $\begin{array}{c}\text { Koefisien } \\
\text { Korelasi (r) }\end{array}$ & $\begin{array}{c}\text { Nilai } \\
\text { Signifikansi }\end{array}$ & Keterangan \\
\hline \multicolumn{4}{|l|}{ 1. Aspek Sumber Daya Manusia } \\
\hline a. Seleksi penerimaan karyawan & 0.662 & 0.000 & Valid \\
\hline b. Berjiwa kepemimpinan & 0.686 & 0.000 & Valid \\
\hline c. Pengalaman kerja penting & 0.630 & 0.000 & Valid \\
\hline d. Memotivasi karyawan & 0.628 & 0.000 & Valid \\
\hline e. Ada job description & 0.722 & 0.000 & Valid \\
\hline \multicolumn{4}{|l|}{ 2. Aspek Keuangan } \\
\hline a. Permodalan mandiri & 0.648 & 0.000 & Valid \\
\hline b. Perputaran laba sebagai modal & 0.675 & 0.000 & Valid \\
\hline c. Mempunyai kemampuan analisis laba & 0.850 & 0.000 & Valid \\
\hline d. Meminimalisir pinjaman & 0.707 & 0.000 & Valid \\
\hline \multicolumn{4}{|l|}{ 3. Aspek Produksi dan Operasional } \\
\hline a. Inovasi produk & 0.825 & 0.000 & Valid \\
\hline b. Ada peralatan untuk mempercepat produksi & 0.805 & 0.000 & Valid \\
\hline c. Peremajaan alat produksi & 0.873 & 0.000 & Valid \\
\hline d. Teknologi membantu produksi & 0.802 & 0.000 & Valid \\
\hline \multicolumn{4}{|l|}{ 4. Aspek Pemasaran } \\
\hline a. Segmentasi pasar & 0.642 & 0.000 & Valid \\
\hline b. Memprioritaskan kualitas produk & 0.740 & 0.000 & Valid \\
\hline
\end{tabular}




\begin{tabular}{llll}
\hline c. Harga dan kualitas kompetitif & 0.807 & 0.000 & Valid \\
d. Promosi & 0.763 & 0.000 & Valid \\
\hline
\end{tabular}

Tabel 3. Hasil Pengujian Validitas Kinerja

\begin{tabular}{lrrc}
\hline \multicolumn{1}{c}{ Variabel / Indikator } & $\begin{array}{c}\text { Koefisien } \\
\text { Korelasi (r) }\end{array}$ & $\begin{array}{c}\text { Nilai } \\
\text { Signifikansi }\end{array}$ & Keterangan \\
\hline 1. Penigkatan kuantitas produk & 0.788 & 0.000 & Valid \\
2. Peningkatan laba & 0.619 & 0.000 & Valid \\
3. Peningkatan modal & 0.857 & 0.000 & Valid \\
4. Peningkatan pelanggan & 0.630 & 0.000 & Valid \\
5. Kesesuaian tujuan dan target & 0.789 & 0.000 & Valid \\
6. Perkembangan usaha & 0.527 & 0.000 & Valid \\
\hline
\end{tabular}

Berdasarkan Tabel 1, 2 dan 3 besar dari taraf nyata 5\%. Pada tabel 4, 5 menunjukkan bahwa item pernyataan dan 6 juga diketahui bahwa variabel / yang digunakan untuk mengukur masing subvariabel dalam penelitian ini - masing variabel yaitu faktor eksternal, dikatakan reliabel. Hal ini ditunjukkan faktor internal dan kinerja UMKM dengan nilai Alpha Cronbach's untuk dinyatakan valid. Hal ini dilihat masing - masing subvariabel maupun berdasarkan nilai signifikansi yang lebih $\quad$ variabel lebih besar dari 0.6.

Tabel 4. Hasil Pengujian Reliabilitas Faktor Eksternal

\begin{tabular}{lcc}
\hline \multicolumn{1}{c}{ Variabel / Indikator } & Nilai Alpha Cronbach's & Keterangan \\
\hline 1. Aspek Kebijakan Pemerintah & 0.791 & Reliabel \\
2. Aspek Sosial Ekonomi & 0.692 & Reliabel \\
3. Aspek Peranan Lembaga Terkait & 0.774 & Reliabel \\
\hline
\end{tabular}

Tabel 5. Hasil Pengujian Reliabilitas Faktor Internal

\begin{tabular}{lcc}
\hline \multicolumn{1}{c}{ Variabel / Indikator } & Nilai Alpha Cronbach's & Keterangan \\
\hline 1. Aspek Sumber Daya Manusia & 0.645 & Reliabel \\
2. Aspek Keuangan & 0.674 & Reliabel \\
3. Aspek Produksi dan Operasional & 0.803 & Reliabel \\
4. Aspek Pemasaran & 0.631 & Reliabel \\
\hline
\end{tabular}

Tabel 6. Hasil Pengujian Reliabilitas Kinerja

\begin{tabular}{lccc}
\hline & Variabel / Indikator & Nilai Alpha Cronbach's & Keterangan \\
\hline Kinerja & 0.774 & Reliabel \\
\hline
\end{tabular}


Sebelum dilakukan pengujian dua kriteria, yaitu Variance Inflation hipotesis, dalam analisis regresi linier Factor (VIF) dan nilai tolerance. Suatu beganda dilakukan pengujian asumsi, variabel dikatakan bebas salah satunya adalah asumsi multikolinearitas jika nilai VIF lebih multikolinearitas. Pengujian kecil dari 10 dan nilai tolerance lebih multikolinearitas bertujuan untuk besar dari 0.10. Hasil pengujian menguji apakah dalam model regresi mulitikolinearitas disajikan pada Tabel 5, ditemukan adanya korelasi antarvariabel tampak bahwa tidak terjadi kolinearitas independen. Model regresi yang baik antarvariabel independen yang terlibat adalah model regresi dimana tidak terjadi dalam penelitian. Hal ini dibuktikan korelasi antarvariabel independen dengan nilai VIF dan nilai tolerance dari (Jeshim dan Kuc, 2002). Variabel setiap variabel independen lebih kecil independen sebanyak 7 dianalisis dari 10 dan lebih besar dari 0.10 . kolinearitasnya dengan menggunakan

Tabel 5. Hasil Pengujian Multikolinearitas

\begin{tabular}{lccc}
\hline \multicolumn{1}{c}{ Variabel Independen } & Nilai VIF & $\begin{array}{c}\text { Nilai } \\
\text { Tolerance }\end{array}$ & Keterangan \\
\hline Kebijakan Pemerintah (X1) & 1.443 & 0.693 & \\
Kondisi Sosial Ekonomi (X2) & 1.246 & 0.802 & Tidak Terjadi \\
Peranan Lembaga Terkait (X3) & 1.542 & 0.649 & Kolinearitas \\
Sumber Daya Manusia (Y1) & 1.225 & 0.816 & antarvariabel \\
Keuangan (Y2) & 1.379 & 0.725 & Independen \\
Operasional (Y3) & 1.583 & 0.632 & \\
Pemasaran (Y4) & 0.615 & 0.619 & \\
\hline
\end{tabular}

3.2 Pemilihan Parameter Model kriteria yang digunakan dalam

\section{Stepwise}

Pemilihan variabel independen yang mempunyai pengaruh signifikan terhadap kinerja umkm Kota Pasuruan melibatkan serangkaian proses dengan kriteria tertentu. Dalam penelitian ini, menentukan model terbaik adalah menggunakan nilai R-Square. Dalam penelitian ini terdapat 3 variabel yang berpengaruh signifikan terhadap kinerja umkm Kota Pasuruan, secara detail dijelaskan pada Tabel berikut :

Tabel 6. Koefisien Determinasi Model Regresi yang Terbentuk 


\begin{tabular}{cccc}
\hline Model & $\mathrm{R}$ & R Square & Variabel Independen yang terlibat \\
\hline 1 & 0.301 & 0.090 & Pemasaran \\
2 & 0.361 & 0.130 & Pemasaran, Keuangan \\
3 & 0.425 & 0.181 & Pemasaran, Keuangan, Kebijakan Pemerintah \\
\hline
\end{tabular}

Model pertama menjelaskan bahwa kinerja umkm Kota Pasuruan dipengaruhi oleh faktor internal yaitu aspek pemasaran dengan nilai koefisien determinasi sebesar 9\%. Kemudian, proses pemilihan model terbaik dengan memilih variabel yang mempunyai pengaruh signifikan terhadap kinerja umkm Kota Pasuruan, dalam model kedua diketahui bahwa kinerja umkm dijelaskan oleh aspek pemasaran dan keuangan dengan nilai R-Square sebesar 13\%. Untuk model regresi berikutnya dengan 3 variabel independen yang mempunyai pengaruh signifikan terhadap kinerja umkm, yaitu aspek pemasaran, keuangan dan kebijakan pemerintah dengan koefisien determinasi sebesar $18.1 \%$.

Tabel 7. Pengujian Simultan dengan Uji F dari Model Regresi yang Terbentuk

\begin{tabular}{|c|c|c|c|c|c|c|c|}
\hline Model & & $\begin{array}{l}\text { Sum of } \\
\text { Square }\end{array}$ & $\mathrm{df}$ & $\begin{array}{c}\text { Mean } \\
\text { Square }\end{array}$ & $\mathrm{F}$ & Sig. & Keterangan \\
\hline \multirow{3}{*}{1} & Regression & 4.123 & 1 & 4.123 & 14.723 & 0.000 & Signifikan \\
\hline & Residual & 41.450 & 148 & 0.280 & & & \\
\hline & Total & 45.573 & 149 & & & & \\
\hline \multirow{3}{*}{2} & Regression & 5.926 & 2 & 2.963 & 10.985 & 0.000 & Signifikan \\
\hline & Residual & 39.648 & 147 & 0.270 & & & \\
\hline & Total & 45.573 & 149 & & & & \\
\hline \multirow{3}{*}{3} & Regression & 8.227 & 3 & 2.742 & 10.720 & 0.000 & Signifikan \\
\hline & Residual & 37.347 & 146 & 0.256 & & & \\
\hline & Total & 45.573 & 149 & & & & \\
\hline
\end{tabular}

Pengujian model regresi yang terbentuk secara simultan ditunjukkan pada Tabel 7, tampak bahwa ketiga model regresi yang terbentuk mempunyai pengaruh terhadap kinerja umkm. Hal ini terlihat

Tabel 8. Pengujian Parsial dengan Uji t dari Model Regresi yang Terbentuk dari nilai signifikansi yang diperoleh setiap model lebih kecil dari taraf nyata $5 \%$.

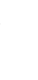




\begin{tabular}{|c|c|c|c|c|c|c|c|}
\hline \multirow{3}{*}{ Model } & \multirow{3}{*}{ Variabel } & \multirow{2}{*}{\multicolumn{2}{|c|}{$\begin{array}{l}\text { Unstandardized } \\
\text { Coefficients }\end{array}$}} & \multirow{3}{*}{$\begin{array}{c}\begin{array}{c}\text { Standardized } \\
\text { Coefficients }\end{array} \\
\text { Beta }\end{array}$} & \multirow{3}{*}{$\mathrm{t}$} & \multirow{3}{*}{ Sig. } & \multirow{3}{*}{ Keterangan } \\
\hline & & & & & & & \\
\hline & & B & Std Error & & & & \\
\hline \multirow{2}{*}{1} & Constant & 2.627 & 0.347 & & 7.576 & 0.000 & Signifikan \\
\hline & Pemasaran & 0.307 & 0.080 & 0.301 & 3.837 & 0.000 & Signifikan \\
\hline \multirow{3}{*}{2} & Constant & 2.016 & 0.414 & & 4.867 & 0.000 & Signifikan \\
\hline & Pemasaran & 0.215 & 0.081 & 0.246 & 3.090 & 0.002 & Signifikan \\
\hline & Keuangan & 0.193 & 0.075 & 0.206 & 2.585 & 0.011 & Signifikan \\
\hline \multirow{5}{*}{3} & Constant & 1.655 & 0.421 & & 3.932 & 0.000 & Signifikan \\
\hline & Pemasaran & 0.194 & 0.081 & 0.190 & 2.385 & 0.018 & Signifikan \\
\hline & Keuangan & 0.224 & 0.073 & 0.239 & 3.048 & 0.003 & Signifikan \\
\hline & Kebijakan & 0.138 & 0.046 & 0.232 & 2.999 & 0.003 & Signifikan \\
\hline & Pemerintah & & & & & & \\
\hline
\end{tabular}

Berdasarkan hasil pengujian parsial dengan menggunakan uji t, diketahui bahwa pada model regresi pertama diperoleh variabel independen, yaitu aspek pemasaran yang berpengaruh signifikan terhadap kinerja umkm Kota Pasuruan dengan nilai signifikansi sebesar 0.000 dan koefisien regresi sebesar 0.301. Pada model regresi yang kedua, diketahui variabel independen yang mempengaruhi kinerja umkm Kota Pasuruan adalah aspek pemasaran dan keuangan. Aspek pemasaran berpengaruh positif terhadap kinerja umkm Kota Pasuruan dengan nilai signifikansi sebesar 0.002 dan koefisien regresi sebesar 0.246, sedangkan aspek keuangan berpengaruh positif terhadap kinerja umkm Kota Pasuruan dengan nilai signifikansi sebesar 0.011 dan koefisien regresi 0.206. Model regresi terbaik dengan 3 variabel independen yaitu aspek pemasaran, aspek keuangan dan aspek kebijakan pemerintah. Variabel independen yang paling dominan adalah aspek keuangan dengan nilai signifikansi sebesar 0.003 dan koefisien regresi sebesar 0.239, kemudian aspek kebijakan pemerintah dengan nilai signifikansi sebesar 0.003 dan koefisien regresi sebesar 0.232. Selain itu, kinerja umkm Kota Pasuruan dipengaruh oleh pemasaran dengan nilai signifikansi sebesar 0.018 dan koefisien regresi sebesar 0.190 .

\subsection{Pembahasan}

Kinerja umkm Kota Pasuruan dipengaruhi oleh faktor eksternal dan faktor internal, dimana faktor eksternal terdiri dari kebijakan pemerintah, kondisi sosial ekonomi dan peranan lembaga 
terkait sedangkan faktor internal terdiri dari aspek sumber daya manusia, aspek keuangan, aspek operasional dan aspek pemasaran. Berdasarkan hasil analisis, diketahui bahwa faktor internal yang mempengaruhi kinerja umkm adalah aspek pemasaran dan aspek keuangan. Kedua variabel tersebut berpengaruh signifikan dan positif terhadap kinerja umkm Kota Pasuruan. Semakin baik pemasaran yang dilakukan maka semakin baik pula kinerja umkm. Kepengurusan yang baik dalam bidang keuangan juga memberikan dampak positif terhadap kinerja umkm. Faktor eksternal yang berpengaruh signifikan terhadap kinerja umkm Kota Pasuruan adalah kebijakan pemerintah.

Hasil penelitian ini tidak sejalan dengan penelitian Krisdanti dan Rodhiyah (2014) dimana sumber daya manusia mempunyai pengaruh yang positif dan signifikan terhadap kinerja umkm, semakin meningkat sumber daya manusia maka akan semakin meningkat pula kinerjanya. Dalam penelitian ini, aspek sumber daya manusia mempunyai pengaruh yang tidak signifikan terhadap kinerja umkm di Kota Pasuruan. Dalam penelitian ini, aspek operasional dan peranan lembaga terkait tidak mempunyai pengaruh signifikan terhadap kinerja umkm. Hal ini sejalan dengan penelitian yang telah dilakukan oleh Purwidianti dan Rahayu (2015) yang menyatakan bahwa kedua variabel tidak mempunyai pengaruh signifikan terhadap kinerja umkm di Purwokerto Utara.

\section{PENUTUP}

\subsection{Kesimpulan}

Berdasarkan hasil analisis yang telah dilakukan maka dapat ditarik beberapa kesimpulan sebagai berikut :

1. Faktor eksternal yang berpengaruh positif dan signifikan terhadap kinerja umkm Kota Pasuruan adalah kebijakan pemerintah

2. Faktor internal yang berpengaruh positif dan signifikan terhadap kinerja umkm Kota Pasuruan adalah aspek pemasaran dan aspek keuangan.

3. Faktor yang berpengaruh dominan terhadap kinerja umkm Kota Pasuruan adalah aspek keuangan.

\subsection{Saran}

Berdasarkan beberapa hal yang telah disimpulkan dapat disampaikan beberapa saran baik bagi pemerintah, pelaku usaha maupun untuk keberlanjutan penelitian.

1. Kepada para pelaku usaha mikro kecil dan menengah untuk selalu berinovasi 
guna meningkatkan pertumbuhan usaha yang telah dirintisnya.

2. Hendaknya peraturan yang dibuat pemerintah lebih pro terhadap bisnis usaha mikro kecil dan menengah serta lebih memperhatikan pertumbuhan usaha mikro kecil dan menengah.

3. Untuk penelitian selanjutnya bisa dilakukan dengan sampel yang lebih spesifik.

\section{UCAPAN TERIMA KASIH}

Terima kasih penulis ucapkan kepada pihak - pihak yang turut membantu di antaranya kepada Kemenristekdikti yang telah memberikan dukungan dana atas terselesaikannya penelitian ini melalui Hibah Dikti dengan Skema Penelitian Dosen Pemula Tahun Pelaksanaan 2018, kepada lembaga penelitian dan pengabdian masyarakat Universitas Merdeka Pasuruan, rekan rekan dosen serta pelaku usaha kecil dan menengah di Kota Pasuruan atas terselesaikannya penelitian ini.

\section{DAFTAR PUSTAKA}

Arikunto, S. 2010. Prosedur Penelitian Suatu Pendekatan Praktik. Jakarta : Rineka Cipta.
David, Fred R. 2009. Strategic Management: Concepts and Cases, Twelfth Edition, Pearson Prentice Hall, New Jersey.

Fahrmeir L, T. Kneib, S. Lang and B. Marx. 2013. Regression: Models, Methods and Applications. Springer Publication 2013.

Hanke, J.E. and Wichern, D.E. 2005. Business Forecasting 8th Ed. New Jersey: Pearson Education.

Jeeshim and Kucc, 2002. Multicolliniearity in Regression Model. Diakses online pada http://php.indiana. edu/ kucc625 1 Multicollinearity in Regression Models.

Keith, T. 2015. Multiple Regression and Beyond An Introduction to Multiple Regression and Structural Equation Modeling 2nd Edition Routledge Pub, Taylor and Francis New York

Krisdanti, G dan Rodhiyah. 2014. Analisis Faktor - faktor yang Mempengaruhi Kinerja UKM pada Sektor Industri Pengolahan 
Makanan di Kota Semarang.

Fakultas Ilmu Sosial dan Politik, Universitas

Diponegoro.

Semarang.

Lofian, Budi dan Riyoko, Sisno. 2014. Identifikasi Faktor Eksternal dan Faktor Internal yang Berpengaruh terhadap Kinerja UKM Mebel Rotan di Jepara. Jurnal DISPROTEK, Vol.5, No. 2.

Munizu, Musran. 2010. Pengaruh Faktor - Faktor Eksternal dan Internal Terhadap Kinerja Usaha Mikro dan Kecil (UMK) di Sulawesi Selatan. Jurnal Manajemen dan Kewirausahaan 12, $33-41$.

Pearce, John A. dan Richard B. Robinson. 2011. Strategic Management Formulation, Implementation, and Control, Twelfth Edition, McGrawHill, New York.

Purwidianti, Widya dan Rahayu, Tri Septin Muji. 2015. Pengaruh Faktor Internal dan Eksternal terhadap Kinerja Usaha Industri Kecil dan Menengah di Purwokerto Utara. Kinerja, Vol. 19, No. 1, Hal. 149 - 159.
Rangkuti, Freddy. 2013. Analisis SWOT Teknik Membedah Kasus Bisnis. Jakarta Gramedia.

Rokhayati, Isnaeni dan Lestari, Herwick Diyah. 2016. Analisis Faktor Faktor yang Mempengaruhi Kinerja UMKM Gula Kelapa di Kabupaten Banyumas, Jawa Tengah. Jaringan Penelitian dan Pengembangan.

Sandra, Alex dan Purwanto, Edi. 2015. Pengaruh Faktor - Faktor Eksternal dan Internal terhadap Kinerja Usaha Kecil dan Menengah di Jakarta. Business Management Journal, Vol. 11, No. 1.

Tambunan, T. 2008. Daya Saing Global Indonesia 2008 - 2009 versi World Economic Forum (WEF). Jakarta : Makalah Kadin.

Zimmerer, Thomas W. et al. 2008. Kewirausahaan dan Manajemen Usaha Kecil, Edisi Kelima, Salemba Empat, Jakarta. 